\title{
Anthropogenic Release and Distribution of Titanium Dioxide Particles in a River Downstream of a Nanomaterial Manufacturer Industrial Site
}

Danielle L. Slomberg ${ }^{1}$, Mélanie Auffan ${ }^{1,2}$, Nelly Guéniche ${ }^{1}$, Bernard Angeletti ${ }^{1}$, Andrea Campos ${ }^{3}$, Daniel Borschneck ${ }^{1}$, Olivier Aguerre-Chariol ${ }^{4}$ and Jérôme Rose ${ }^{1,2 *}$

${ }^{1}$ CNRS, Aix-Marseille Univ., IRD, INRAE, Coll France, CEREGE, Aix-en-Provence, France, ${ }^{2}$ Civil and Environmental Engineering Department, Duke University, Durham, NC, United States, ${ }^{3}$ Aix-Marseille Univ., CNRS, Centrale Marseille, FSCM (FR1739), Marseille, France, ${ }^{4}$ INERIS, Verneuil-en-Halatte, France

OPEN ACCESS

Edited by:

Denise M. Mitrano,

Swiss Federal Institute of Aquatic Science and Technology, Switzerland

Reviewed by:

Kevin Wikinson,

Université de Montréal, Canada

Mohammed Baalousha,

University of South Carolina,

United States

*Correspondence: Jérôme Rose rose@cerege.fr

Specialty section: This article was submitted to

Biogeochemical Dynamics,

a section of the journal

Frontiers in Environmental Science

Received: 31 March 2020 Accepted: 18 May 2020

Published: 16 June 2020

Citation:

Slomberg DL, Auffan M, Guéniche N, Angeletti B, Campos A,

Borschneck D, Aguerre-Chariol $O$ and Rose J (2020) Anthropogenic Release and Distribution of Titanium Dioxide Particles in a River Downstream of a Nanomaterial Manufacturer Industrial

Site. Front. Environ. Sci. 8:76.

doi: 10.3389/fenvs.2020.00076
Several industries manufacture and process large quantities of engineered nanomaterials, thus increasing the potential for their environmental release during waste management and disposal. Herein, we quantified the release and spatial distribution of titanium dioxide nanomaterials $\left(\mathrm{TiO}_{2} \mathrm{NMs}\right)$ emitted from an industrial waste stream that flows into a nearby river. Two sampling campaigns were carried out on the river in fall 2017 and spring 2018 at selected sites upstream and downstream of the Industrial Effluent and an urban wastewater treatment plant (WWTP). Significant $\mathrm{Ti}$ accumulation was detected in the sediments at the Industrial Effluent and WWTP sites for both fall and spring samples, with measured Ti concentrations of 75-193 mg Ti/kg reaching $21-55 \times$ that of the local background upstream. X-ray diffraction analysis confirmed the anatase and rutile mineralogy of the inputs. River surface waters were filtered on-site to distinguish between particulate $(>0.20 \mu \mathrm{m})$, colloidal $(0.02-0.20 \mu \mathrm{m})$, and dissolved and/or small nanoparticulate (NP) $(<0.02 \mu \mathrm{m}) \mathrm{TiO}_{2}$. Up to 133 and 260 $\mu \mathrm{g} \mathrm{Ti} / L$ were measured in the unfiltered waters for the Industrial Effluent and WWTP fall samples, respectively, while the spring samples exhibited Ti concentrations similar to the background concentration. Combining chemical analysis and scanning electron microscopy revealed that some Ti particles recovered from the Industrial Effluent and WWTP were clusters of $\mathrm{TiO}_{2} \mathrm{NMs}(\sim 50 \mathrm{~nm})$. Furthermore, anthropogenic $\mathrm{TiO}_{2}$ was distinguished apart from natural Ti-containing minerals by comparing the concentration ratios between $\mathrm{Ti}$ and other naturally occurring elements (e.g., V, Al, and Fe). This study confirmed the release of manufactured $\mathrm{TiO}_{2} \mathrm{NMs}$ from the Industrial Effluent and the WWTP into the river, finding that almost all of the $\mathrm{TiO}_{2} \mathrm{NMs}$ are released in the particulate fraction $(>0.20 \mu \mathrm{m})$, and that the particles sediment rapidly near the emission source and accumulate in the sediment.

Keywords: manufactured $\mathrm{TiO}_{2}$ nanomaterials, anthropogenic emission, river ecosystem, environmental exposure, aggregation, sediment accumulation 


\section{INTRODUCTION}

As advances in nanotechnology research and development continue, engineered nanomaterials are being increasingly manufactured for incorporation into consumer products destined for cosmetic, textile, coating, and plastic applications (Piccinno et al., 2012; Vance et al., 2015). Several recent studies have considered the environmental impacts of nanomaterials released from these consumer products during their use phase and end-of-life (Botta et al., 2011; Nowack et al., 2012; Mitrano et al., 2015; Auffan et al., 2018; Scifo et al., 2018), but another important consideration is the possible release and local environmental accumulation near nanomaterial manufacturing sites, especially those close to aquatic ecosystems such as rivers and lakes. Upon incidental or direct release into these natural systems, nanomaterial fate, and transport are governed by the water chemistry, particle aggregation state, and any transformation processes (e.g., dissolution, photochemical alteration, oxidation and reduction) (Nowack et al., 2012).

In the case of titanium dioxide nanomaterials $\left(\mathrm{TiO}_{2} \mathrm{NMs}\right)$, the second most-produced nanomaterial worldwide (Sun et al., 2014), previous research has already focused on evaluating their fate and behavior in model river waters, with the aim of determining their potential risk. Indeed, the aggregation and sedimentation of two of the most common $\mathrm{TiO}_{2} \mathrm{NM}$ forms, anatase and rutile, have been shown to depend on particle morphology, the point of zero charge, and water conditions (Liu et al., 2011; Ilina et al., 2017). Besides the physicochemical characteristics of the $\mathrm{TiO}_{2} \mathrm{NMs}$ themselves and the $\mathrm{pH}$ of the aqueous environment, the presence of dissolved ions, suspended particulate matter (SPM), and natural organic matter (NOM) can also significantly influence NM stability through processes such as aggregation and sedimentation or dispersion and transport (Loosli et al., 2013; Labille et al., 2015; Slomberg et al., 2019). For example, increased ionic strength and divalent cation concentrations have been shown to facilitate $\mathrm{TiO}_{2} \mathrm{NM}$ homo-aggregate formation (Loosli et al., 2013; Ilina et al., 2017). However, in natural aqueous environments where SPM and NOM concentrations $(\mathrm{mg} / \mathrm{L})$ are likely much higher than the predicted $\mathrm{TiO}_{2} \mathrm{NM}$ concentration $(\mu \mathrm{g} / \mathrm{L})$, heteroaggregation is expected to be the more dominant interaction driving NM fate and behavior (Labille et al., 2015). As such, Adam et al. evaluated both $\mathrm{TiO}_{2} \mathrm{NM}$ homo-aggregation and hetero-aggregation interactions with illite clay and Suwannee River fulvic acid (SRFA) in filtered river water ( $\mathrm{pH}$ 8) sampled nearby the $\mathrm{TiO}_{2} \mathrm{NM}$ manufacturing site (Adam et al., 2016). In lower salinity conditions $\left(0.25 \mathrm{mM} \mathrm{Ca}^{2+}\right)$ the $5 \mathrm{~nm} \mathrm{TiO} 2$ particles $(40 \mathrm{mg} / \mathrm{L})$ formed homo-aggregates $(\sim 550 \mathrm{~nm})$. The addition of SRFA (5-10 mg/L) slightly enhanced $\mathrm{TiO}_{2} \mathrm{NM}$ dispersion and decreased the overall $\mathrm{TiO}_{2}$ aggregate size, and in the presence of illite $(25 \mathrm{mg} / \mathrm{L})$ no secondary hetero-aggregation was observed. Yet, when the river water $\mathrm{Ca}^{2+}$ concentration was increased to $3 \mathrm{mM}$, the decrease in $\mathrm{TiO}_{2} \mathrm{NM}$ homo-aggregate size was no longer observed in the presence of SRFA and the addition of illite resulted in hetero-aggregation, thus favoring NM sedimentation.

Multimedia environmental fate models have also been developed to investigate NM fate and transport in rivers as a complement to experimental approaches. Any NM inputs into river surface waters should be detected almost instantaneously, although their lifetime in the water column may be transient due to aggregation processes and changes in hydrological conditions. For NMs that are not stable in the water column, the riverbed sediment can act as a sink where the NMs will deposit and potentially accumulate as long as the NM emission continues. For example, river box models incorporating fixed or varied water conditions in time and space have examined $\mathrm{TiO}_{2} \mathrm{NM}$ fate in surface waters and sediment for two large European rivers, the Rhine, and the Rhone (Praetorius et al., 2012; Sani-Kast et al., 2015). In both cases, for a constant, point source $\mathrm{TiO}_{2} \mathrm{NM}$ emission of $0.39-1.5 \mathrm{~kg} /$ day, predicted $\mathrm{TiO}_{2} \mathrm{NM}$ concentrations were in the $\mathrm{ng} / \mathrm{L}$ range for the water compartment and $\mathrm{mg} / \mathrm{kg}$ in the sediment. $\mathrm{TiO}_{2} \mathrm{NM}$ fate was dependent on the water conditions near the emission source, with significant aggregation, sedimentation, and accumulation in the sediment layer occurring within a few $\mathrm{km}$ of $\mathrm{NM}$ release. However, these models also predicted that a fraction of $\mathrm{TiO}_{2} \mathrm{NMs}$ can remain stable in the water column, being transported up to $\sim 100 \mathrm{~km}$ from the source depending on river conditions.

While laboratory studies with simulated aquatic systems and the development of environmental fate models have allowed researchers to gain insight into $\mathrm{TiO}_{2} \mathrm{NM}$ transport, behavior, and fate, field studies to determine NM release and accumulation in real aqueous environments are still lacking. This is in part due to the fact that detecting and quantifying low concentrations of anthropogenic $\mathrm{TiO}_{2} \mathrm{NMs}$ apart from the natural background is analytically challenging. Recent approaches include a combination of size fractionation (e.g., filtration, field-flow fractionation) followed by identification and quantification using elemental analysis (i.e., inductively coupled plasma-mass spectrometry, ICP-MS) and electron microscopy coupled with X-ray energy dispersive spectroscopy (EDS) detection (Von der Kammer et al., 2011, 2012; Westerhoff et al., 2011; Labille et al., 2019). For example, three different sampling campaigns that analyzed filtered waters $(<0.45 \mu \mathrm{m})$ near a wastewater treatment plant (WWTP) confirmed $\mathrm{TiO}_{2}$ NM presence with electron microscopy and reported Ti values between 0.7 and $3 \mu \mathrm{g} / \mathrm{L}$ (Johnson et al., 2011; de Klein et al., 2016; Markus et al., 2018). Single particle (SP)-ICP-MS was utilized to target and detect smaller $\mathrm{TiO}_{2}$ particles down to $100 \mathrm{~nm}$ in river surface waters without the need for filtration (Peters et al., 2018), and Hadioui et al. (2019) have now detected $\mathrm{TiO}_{2}$ particle sizes down to $19.2 \mathrm{~nm}$ with the technique. While progress has been made in detecting low concentrations of $\mathrm{TiO}_{2}$ NMs $(\mu \mathrm{g} / \mathrm{L})$ in complex environmental matrices, these analyses alone cannot confirm that the particles are anthropogenic. As such, the determination of elemental ratios between $\mathrm{Ti}$ and other naturally occurring elements such as $\mathrm{V}, \mathrm{Al}$, and $\mathrm{Fe}$, or rare earth elements ( $\mathrm{Ga}, \mathrm{Y}, \mathrm{Nb}, \mathrm{Eu}, \mathrm{Ho}, \mathrm{Er}, \mathrm{Tm}, \mathrm{Yb}, \mathrm{Ta})$ has been employed to distinguish natural Ti-containing particles from the anthropogenic load in aquatic systems as well as soils (Gondikas et al., 2017; Reed et al., 2017; Labille et al., 2019; Baalousha et al., 2020; Wang et al., 2020). Building upon this approach, multi-element (ME)-SP-ICP-MS has been used to perform multi-element analysis of individual $\mathrm{TiO}_{2}$ particles in 


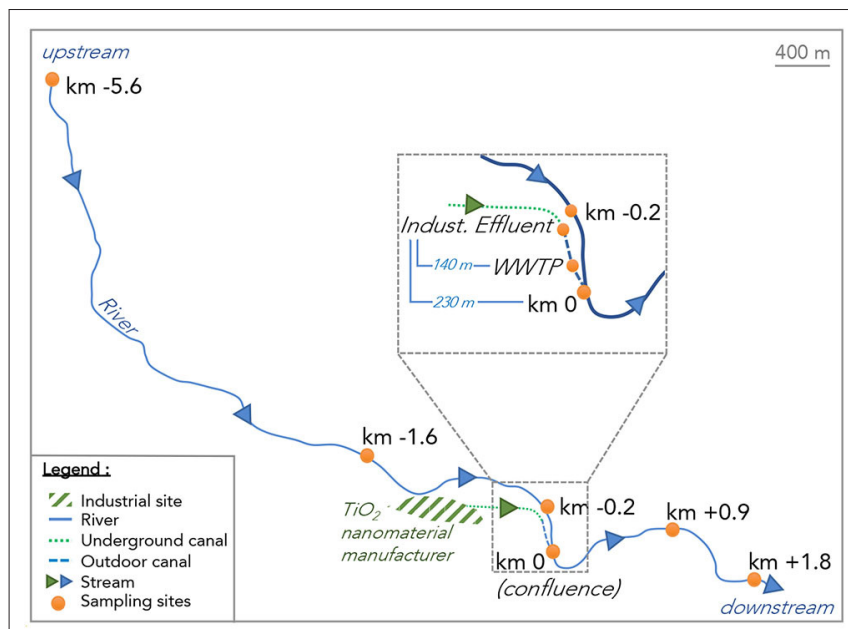

FIGURE 1 | Map of river sampling sites near $\mathrm{TiO}_{2}$ nanomaterial manufacturing plant, with distances along the river given relative to the confluence of the industrial drainage canal and the river at $\mathrm{km} 0$.

natural surface waters (Gondikas et al., 2018; Loosli et al., 2019). By identifying multi-element signatures of natural Ti-containing particles, anthropogenic $\mathrm{TiO}_{2} \mathrm{NMs}$ can be further distinguished apart from the natural background and quantified. Overall, these studies have demonstrated that $\mathrm{TiO}_{2} \mathrm{NMs}$ can be quantified in natural surface waters, while also providing insight as to their release from WWTPs or other anthropogenic sources. This knowledge is crucial for evaluating $\mathrm{TiO}_{2} \mathrm{NM}$ risk to aquatic ecosystems, yet a comprehensive assessment can only be obtained by also considering $\mathrm{TiO}_{2} \mathrm{NM}$ transport and accumulation in the sediment compartment in future field studies.

The present work reports the first quantification of $\mathrm{TiO}_{2}$ NMs in a river next to a nanomaterial manufacturing plant, both upstream and downstream of the potential emission source (i.e., industrial drainage canal). Surface waters, sediments, and epilithic organisms were collected along the river and industrial drainage canal at two different time periods (October 2017 and March 2018) to assess any short-term, pulse occurrence vs. long-term accumulation in the different environmental compartments. In addition to $\mathrm{TiO}_{2}$ quantification, anatase and rutile inputs into the river were distinguished from the local background using mineralogical analysis. Several elements (X $=\mathrm{V}, \mathrm{Al}$, and $\mathrm{Fe}$ ) naturally co-occurring with $\mathrm{Ti}$ in suspended mineral particles were also quantified to determine $\mathrm{Ti} / \mathrm{X}$ elemental ratios. Higher elemental ratios compared to the natural background were used as an indication of $\mathrm{Ti}$ of anthropogenic origin. By sampling the water and sediment compartments at multiple sites along the river, $\mathrm{TiO}_{2} \mathrm{NM}$ transport and fate were determined in a real release scenario.

\section{MATERIALS AND METHODS}

\section{Sampling Campaigns}

The samples were taken along a $7.4 \mathrm{~km}$ long transect in a watershed of about $160 \mathrm{~km}^{2}$ at two different time periods, on
October 18th, 2017 and March 22nd, 2018. For these dates, outflows of $0.98 \pm 0.01 \mathrm{~m}^{3} . \mathrm{s}^{-1}$ and $4.89 \pm 0.01 \mathrm{~m}^{3} . \mathrm{s}^{-1}$ were respectively measured in the river at a hydrology station located $\sim 7 \mathrm{~km}$ upstream from the confluence (http://hydro.eaufrance. $\mathrm{fr} /$ ). The river is characterized by an average annual $\mathrm{pH}$ of 7.6-8.1, dissolved organic carbon (DOC) concentration of 1.8$2.3 \mathrm{mg} / \mathrm{L}$, and total suspended sediment (TSS) concentration of $\sim 5 \mathrm{mg} / \mathrm{L}$ (Hissler and Probst, 2006; Adam et al., 2016). Eight sampling stations were selected: 6 along the river, upstream and downstream of the $\mathrm{TiO}_{2}$ nanomaterial manufacturing site, and 2 along the drainage canal where treated industrial and urban effluents join the river (Figure 1). The confluence between the drainage canal and the river was referred to as $\mathrm{km} 0$. The 6 sampling stations along the river were located at $5.6 \mathrm{~km}$ $(\mathrm{km}-5.6), 1.6 \mathrm{~km}(\mathrm{~km}-1.6)$, and $0.2 \mathrm{~km}(\mathrm{~km}-0.2)$ upstream of the confluence $(\mathrm{km} 0)$ as well as $0.9 \mathrm{~km}(\mathrm{~km}+0.9)$ and $1.8 \mathrm{~km}(\mathrm{~km}+1.8)$ downstream of the confluence. The effluents from the $\mathrm{TiO}_{2} \mathrm{NM}$ manufacturing site first flow through an underground canal (not accessible) for a distance of $\sim 1 \mathrm{~km}$ before the outdoor section of the drainage canal begins. The 2 sampling stations along this outdoor drainage canal were located at the beginning of the outdoor discharge of the manufacturing site's treated effluent ( $230 \mathrm{~m}$ upstream of the confluence, station called "Industrial Effluent") and at the outflow of the urban waste water treatment plant's (WWTP) treated effluent that also flows into the surface of the water column in the drainage canal $(90 \mathrm{~m}$ upstream of the confluence, station called "WWTP"). No natural water sources are located along this drainage canal and it is surrounded by steep embankments. The distance between the drainage canal and the river at the Industrial Effluent sampling station is $\sim 35 \mathrm{~m}$. The water depth was $\sim 20 \mathrm{~cm}$ in both the drainage canal and river in October 2017 and March 2018.

\section{On-Site Water and Sediment Collection}

Water samples were collected manually in the center of the riverbed. As soon as water samples are collected, the particle size distribution can change rapidly. It was therefore decided to filter on-site to avoid any modification of the size distribution. Water samples were filtered on-site using both 0.20 and $0.02 \mu \mathrm{m}$ inorganic membrane syringe filters [Anodisc $\left(\mathrm{Al}_{2} \mathrm{O}_{3}\right)$, Whatman, UK]. The raw, unfiltered waters and the 0.20 and $0.02 \mu \mathrm{m}$-filtered waters were then brought back to the laboratory and stored at $4^{\circ} \mathrm{C}$ for elemental analysis using inductively coupled plasmamass spectrometry (ICP-MS). The membrane filters were dried $24 \mathrm{~h}$ at room temperature (protected from ambient dust particles) and stored at $4^{\circ} \mathrm{C}$ for scanning electron microscopy (SEM) observation. Water size fractionation was performed to quantify $\mathrm{Ti}$ in the particulate, colloidal, and dissolved fractions. The particulate and colloidal fractions were separated with $0.20 \mu \mathrm{m}$ filters. Ideally, separation of the colloidal and dissolved fractions requires 1 or $3 \mathrm{~K}$-Dalton membranes. The $0.02 \mu \mathrm{m}$ inorganic membranes selected for the current work were therefore unable to isolate the "true" dissolved fraction, and instead resulted in a fraction composed of dissolved plus small nanoparticulate (NP) species. This choice was made due to the operational conditions needed for a fast separation on-site. 
Surface sediment samples (down to $\sim 2 \mathrm{~cm}$ depth) were brought up from the center of the canal/river using a $50 \mathrm{~mL}$ syringe. These sediments were sieved at $1 \mathrm{~mm}$ and then $250 \mu \mathrm{m}$ to remove larger grains and the fraction $<250 \mu \mathrm{m}$ was freezedried and homogenized for X-ray diffraction (XRD) and ICPMS analysis. Natural epilithic organisms were also collected to evaluate $\mathrm{TiO}_{2}$ accumulation. Briefly, a few grams of epilithic organisms were scraped from sedimentary river rocks at 3 sites along the river $(\mathrm{km}-5.6,0,+1.8)$ (Figure $\mathbf{S 1})$. To remove any loosely adhered, small particles, the epilithic organisms were first gently rinsed with ultrapure water on a $20 \mu \mathrm{m}$ sieve, then freeze-dried and homogenized before analysis with ICP-MS.

\section{Mineralogical Analysis}

$\mathrm{X}$-ray diffraction $(\mathrm{XRD})$ was performed on sediment fractions $(<250,1-250$, and $<1 \mu \mathrm{m})$ from 4 sites $(\mathrm{km}-5.6$, Industrial Effluent, WWTP, $\mathrm{km}+1.8$ ) for samples from October 18, 2017 to evaluate the river's background mineralogy of Tibased phases and any anthropogenic $\mathrm{TiO}_{2}$ contributions. The sediment samples from March 2018 were not included in the XRD analysis since they exhibited a similar distribution of $\mathrm{Ti}$ concentrations compared to those from October 2017. Based on previous analysis on the river sediment, we hypothesized that the $<250 \mu \mathrm{m}$ sediment fraction may contain background minerals exhibiting strong signals (e.g., quartz and feldspars) that could make it difficult to distinguish potentially less intense signals of anatase or rutile $\mathrm{TiO}_{2}$ (Hissler and Probst, 2006). Thus, an additional size separation was performed to remove the larger background minerals and obtain a finer sediment fraction of $<1 \mu \mathrm{m}$.

Briefly, the $<1 \mu \mathrm{m}$ fraction was recovered according to Stokes law by re-suspending the $<250 \mu \mathrm{m}$ sediment in ultrapure water $(5.56 \mathrm{~g} / \mathrm{L})$, sonicating $30 \mathrm{~min}$ to break up aggregates, allowing the sample to settle for $186 \mathrm{~min}$, and then collecting the top $4 \mathrm{~cm}$ (quartz density $=2.65 \mathrm{~g} / \mathrm{cm}^{3}$ ) (Rubey, 1933). The recovered $<1 \mu \mathrm{m}$ sediment, along with the remaining $1-250 \mu \mathrm{m}$ fraction were freeze-dried and homogenized before XRD analysis.

The three sediment fractions $(<250,1-250$, and $<1 \mu \mathrm{m})$ were ground with a mortar and pestle before depositing them on XRD low-background silicon plates. The samples were then analyzed with a PANalytical X-Pert PRO (Limeil-Brevannes, France) diffractometer equipped with Co K $\alpha$ radiation (1.79 $\AA$ ) at $40 \mathrm{kV}$ and $40 \mathrm{~mA}$. Each fraction was spun at $15 \mathrm{rpm}$ and scanned with a $2 \theta$ range of $4-75^{\circ}$, step size of $0.033^{\circ}$ and time per step of $4.7 \mathrm{~s}$. Quartz was used as an internal standard to correct displacement of peak positions.

\section{Elemental Analysis}

The fractioned sediment $(<250 \mu \mathrm{m})$, surface waters, and epilithic organisms were subjected to total decomposition using microwave-assisted acid digestion before elemental analysis with ICP-MS. Fifty milligrams of the solid samples (i.e., sediments or epilithic organisms) were digested in an UltraWAVE microwave system (Milestone Inc.) with $1.5 \mathrm{~mL} \mathrm{HCl}, 1 \mathrm{~mL} \mathrm{HNO}_{3}$, and $1 \mathrm{~mL} \mathrm{HF}$ at $180^{\circ} \mathrm{C}$. The raw and filtered surface water samples $(2 \mathrm{~mL})$ were digested in the same system with $1 \mathrm{~mL} \mathrm{HNO}_{3}$ and $0.5 \mathrm{~mL}$ HF. The digested residues were then diluted to
$10 \mathrm{~mL}$ with ultrapure water before analysis for $\mathrm{Ti}, \mathrm{V}, \mathrm{Al}$, and $\mathrm{Fe}$ concentrations using a PerkinElmer NexION 300X quadrupole ICP-MS (measured isotopes $={ }^{47} \mathrm{Ti},{ }^{51} \mathrm{~V},{ }^{27} \mathrm{Al}$, and ${ }^{56} \mathrm{Fe}$ ). A 9496\% Ti recovery was measured for the above protocol using $\mathrm{TiO}_{2}$ NP standards prepared in ultrapure water $(0,10,50,100,500$, and $1,000 \mu \mathrm{g} / \mathrm{L})$. The concentrations of $\mathrm{Na}^{+}, \mathrm{K}^{+}, \mathrm{Mg}^{2+}$, and $\mathrm{Ca}^{2+}$ cations were determined by ICP-MS analysis (measured isotopes $={ }^{23} \mathrm{Na},{ }^{39} \mathrm{~K},{ }^{24} \mathrm{Mg}$, and ${ }^{43} \mathrm{Ca}$ ) of the $0.20 \mu \mathrm{m}$-filtered waters. The raw and filtered $(0.20$ and $0.02 \mu \mathrm{m})$ surface waters collected were analyzed for $\mathrm{Ti}$ concentration to provide insight into the real-time total, particulate $(>0.20 \mu \mathrm{m})$, colloidal $(0.02-0.20 \mu \mathrm{m})$, and dissolved and/or small nanoparticulate $(<0.02 \mu \mathrm{m}) \mathrm{Ti}$ occurrence in the water column. The Ti concentrations in the particulate $(>0.20 \mu \mathrm{m})$ fraction were calculated by subtracting the measured $\mathrm{Ti}$ in the $0.20 \mu \mathrm{m}$-filtered waters from the total $\mathrm{Ti}$ concentration in the raw surface waters. Likewise, the Ti concentration in the colloidal fraction $(0.02-0.20 \mu \mathrm{m})$ was calculated by subtracting the Ti measured in the $0.02 \mu \mathrm{m}$ filtered waters from the Ti concentration measured in the 0.20 $\mu \mathrm{m}$-filtered waters.

To distinguish natural and anthropogenic $\mathrm{TiO}_{2}$ particles, we compared the elemental distributions of the collected natural samples (e.g., sediments and water) to two types of anthropogenic $\mathrm{TiO}_{2}$ nanomaterials (NM1 and NM2) as well as 3 natural minerals (i.e., feldspar, clay, and quartz). NM1 and NM2 were provided as powders by the manufacturing plant located next to the sampled river. The anatase nanomaterials were wellcrystallized and spherical, with a size of approximately $6.5 \pm$ $2.0 \mathrm{~nm}$ (NM1) and $38.8 \pm 2.0 \mathrm{~nm}$ (NM2) from transmission and scanning electron microscopy (Figure S2). It is also worth noting that the manufacturer not only produces nanomaterials, but also larger, submicron-sized pigments. The minerals analyzed were feldspar (albite and microcline of natural origin), clay (kaolinite), and quartz $(<20 \mu \mathrm{m})$. The $\mathrm{TiO}_{2}$ nanomaterials (i.e., NM1 and NM2) and minerals $(50 \mathrm{mg}$ ) were digested using the same microwave-assisted procedure as that selected for the sediments and the resulting residues were diluted and analyzed with inductively coupled plasma-atomic emission spectroscopy (ICP-AES, Perkin Elmer 4300 DV) and ICP-MS for Ti, V, Al, and Fe concentrations.

\section{Imagery and Elemental Detection}

A Zeiss Gemini 500 scanning electron microscope (SEM) equipped with an EDAX Silicon Drift Detector was used to image and determine the elemental composition of surface water particles that had been collected on $0.20 \mu \mathrm{m}$ inorganic membrane filters $\left(\mathrm{Al}_{2} \mathrm{O}_{3}\right)$ on-site at the Industrial Effluent and WWTP discharge sites on October 18, 2017. One membrane filter from each site was attached directly to an aluminum pin stub with double-sided carbon tape and then analyzed without further preparation (e.g., sputter coating). In-lens secondary electron detection was employed for imaging and the microscope was operated at $1 \mathrm{kV}$ with a working distance of $0.5 \mathrm{~mm}$. Elemental analysis using Energy Dispersive Spectroscopy (EDS) was performed at $15 \mathrm{kV}$ with a working distance of $12.3 \mathrm{~mm}$ to evaluate the presence of $\mathrm{Ti}, \mathrm{O}, \mathrm{Al}, \mathrm{Fe}$, and $\mathrm{C}$. 


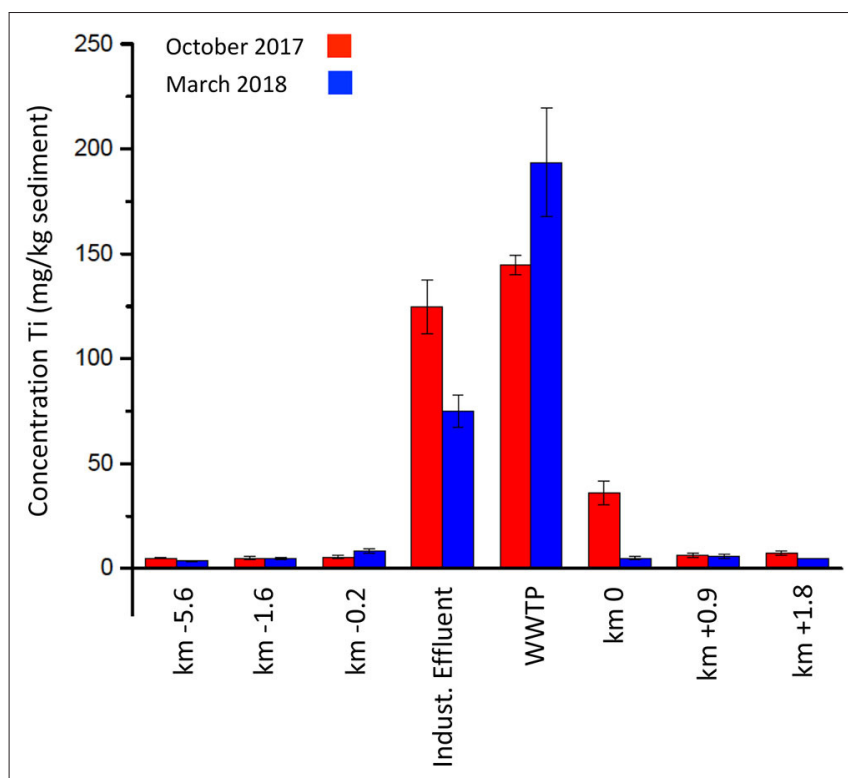

FIGURE 2 | Sediment ( $<250 \mu \mathrm{m}$ ) Ti concentrations (mg Ti/kg sediment) at each sampling site for October 2017 and March 2018. Error bars represent replicate sample digestions of the same sample $(n=3)$.

\section{RESULTS AND DISCUSSION}

\section{Ti Accumulation in Sediment Downstream of the Manufacturing Plant}

The Ti concentrations in the river sediment were determined first to assess potential $\mathrm{TiO}_{2}$ nanomaterial accumulation over time. As shown in Figure 2, similar trends in sediment Ti concentration were observed for the samples collected in October 2017 and March 2018 despite the seasonal differences of the two sampling campaigns. Upstream of the confluence, at $\mathrm{km}-5.6,-1.6$, and -0.2 , the background $\mathrm{Ti}$ concentration in the river sediment was stable at $\sim 5.4 \pm 1.5 \mathrm{mg} / \mathrm{kg}$. However, along the industrial drainage canal, the $\mathrm{Ti}$ concentrations in the sediment were $\sim 21-25 \times$ and $\sim 29-55 \times$ higher than the background for the Industrial Effluent and WWTP sites, respectively. Specifically, concentrations of $124.6 \pm 12.6$ and $75.1 \pm 7.9 \mathrm{mg} \mathrm{Ti} / \mathrm{kg}$ sediment were measured at the Industrial Effluent site, while $144.5 \pm$ 4.6 and $193.6 \pm 25.8 \mathrm{mg} \mathrm{Ti} / \mathrm{kg}$ sediment were detected at the WWTP site for October 2017 and March 2018, respectively. While the measured $\mathrm{Ti}$ concentrations in the canal sediments were higher at the WWTP site compared to the Industrial Effluent discharge site, there is no indication that this increase is related to more Ti-containing particles being discharged from the WWTP effluent. Ti-containing particles discharged from the Industrial Effluent site may be transported $\sim 90 \mathrm{~m}$ downstream before sedimenting at the WWTP site. Furthermore, although there appear to be significant differences in Ti sediment concentrations at the same site between October 2017 and March 2018, the presumed seasonal variations could also be due to difficulties in sampling the exact same sediment during both sampling campaigns. The two canal sites exhibited significant
Ti accumulation, yet downstream of the confluence $(\mathrm{km} 0)$, the sediment $\mathrm{Ti}$ concentrations returned to levels similar to those observed upstream. For example, in October 2017, some Ti accumulation $(36.1 \pm 5.7 \mathrm{mg} / \mathrm{kg})$ was still observed at $\mathrm{km} 0$, but the sediment Ti concentration at $\mathrm{km}+0.9$ was $6.4 \pm 1.0 \mathrm{mg} / \mathrm{kg}$, which was similar to the upstream background of $4.9 \pm 0.3$ $\mathrm{mg} / \mathrm{kg}$ at $\mathrm{km}-5.6$. The sediments collected in March 2018 also exhibited little evidence of $\mathrm{Ti}$ accumulation downstream of the confluence and in fact, the Ti sediment concentration measured at $\mathrm{km} 0$ was comparable to that at $\mathrm{km}-5.6$ ( $4.9 \pm 0.8$ vs. 3.5 $\pm 0.4 \mathrm{mg} \mathrm{Ti} / \mathrm{kg}$ sediment). However, elemental analysis alone cannot be used to verify that this increased $\mathrm{Ti}$ concentration in the sediment resulted from the presence of $\mathrm{TiO}_{2}$ and not another Ti-containing mineral. Furthermore, complementary analyses are required to confirm that the detected Ti results from anthropogenic $\mathrm{TiO}_{2}$.

\section{Anthropogenic vs. Natural Origin of $\mathrm{TiO}_{2}$ in Sediment}

Anatase and rutile were not detected apart from the sediment background upstream at $\mathrm{km}-5.6$ in the $<1$ and $1-250 \mu \mathrm{m}$ sample fractions from October 2017 (Figure 3A). The presence of $\mathrm{TiO}_{2}$ in the canal sediments at the Industrial Effluent and WWTP discharge sites was confirmed, with clear signals observed from both the anatase and rutile main peaks at 29.443 and 31.982 $2 \Theta\left[^{\circ}\right]$, respectively (Figure 3A) (Swanson et al., 1969). Of note, the main quartz peak at $31.0352 \Theta\left[^{\circ}\right]$ is also shown for reference. While anatase $\mathrm{TiO}_{2}$ was detected in both the $<1$ and $1-250 \mu \mathrm{m}$ sediment fractions at the Industrial Effluent site, this form was only detected in the $<1 \mu \mathrm{m}$ sediment fraction at the WWTP site. Similarly, rutile $\mathrm{TiO}_{2}$ was detected in both sediment fractions at the Industrial Effluent site. No significant rutile presence was observed in the $<1 \mu \mathrm{m}$ sediment fraction at the WWTP site, however a strong signal was present in the $1-250 \mu \mathrm{m}$ fraction. Downstream at $\mathrm{km}+1.8$, the presence of anatase was observed in the $<1$ and $1-250 \mu \mathrm{m}$ fractions, but rutile was not detectable (Figure S3). Although anatase and rutile $\mathrm{TiO}_{2}$ both accumulated in the canal sediments at the Industrial Effluent and WWTP discharge sites, the two forms were concentrated differently within the two sediment size fractions, implying that the anatase and rutile $\mathrm{TiO}_{2}$ detected at the two sites may not have the same primary particle size or be distributed within the sediment in the same way (e.g., aggregate formation). The two $\mathrm{TiO}_{2}$ forms may also exhibit different stability and transport in the river water, as suggested by the fact that only the anatase form was detected downstream at $\mathrm{km}+1.8$ (Fazio et al., 2008; Liu et al., 2011; Iswarya et al., 2015).

To go further in determining the origin of the anatase and rutile phases identified with $\mathrm{XRD}, \mathrm{Ti} / \mathrm{X}$ molar ratios (with $\mathrm{X}$ $=\mathrm{V}, \mathrm{Al}$, and $\mathrm{Fe}$ ) of manufactured NMs (NM1 and NM2) and natural minerals (feldspar, clay, and quartz) were compared to the ratios found in the collected river sediments, as shown in Figure 3B (Gondikas et al., 2017, 2018; Reed et al., 2017). The total element concentrations used to calculate these ratios can be found in Table S2. Such analysis of other naturally occurring elements in the sediment was essential for determining whether 
A

A $\cdots \mathrm{km}-5.6$

Indust. Effluent

---- WWTP

Anatase, $\mathrm{TiO}_{2}$
Quartz, $\mathrm{SiO}_{2}$

Rutile, $\mathrm{TiO}_{2}$

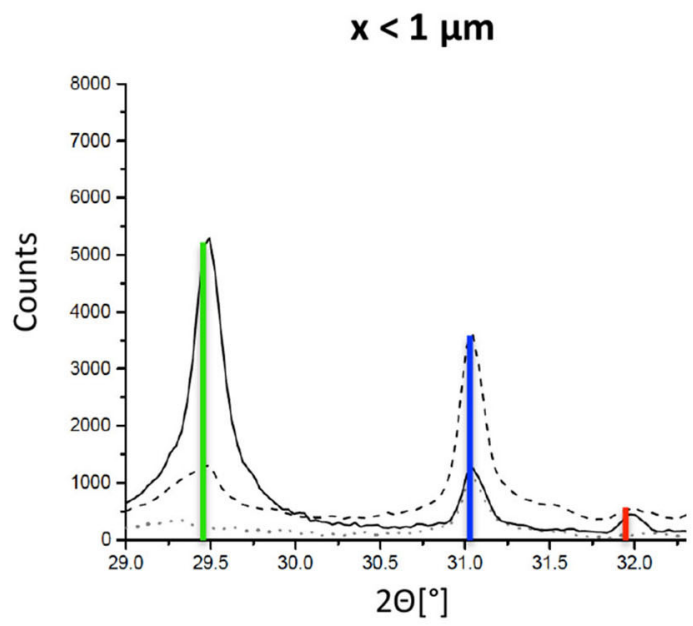

\section{1-250 $\mu \mathrm{m}$}

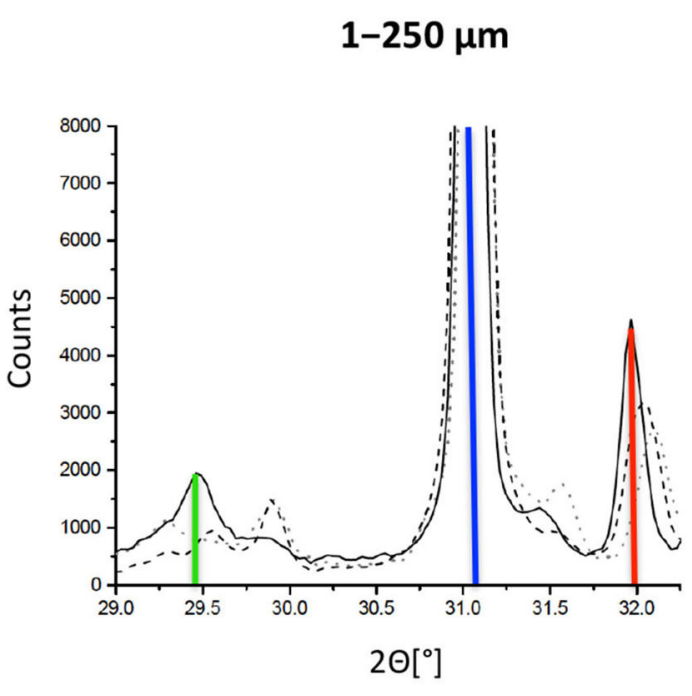

B

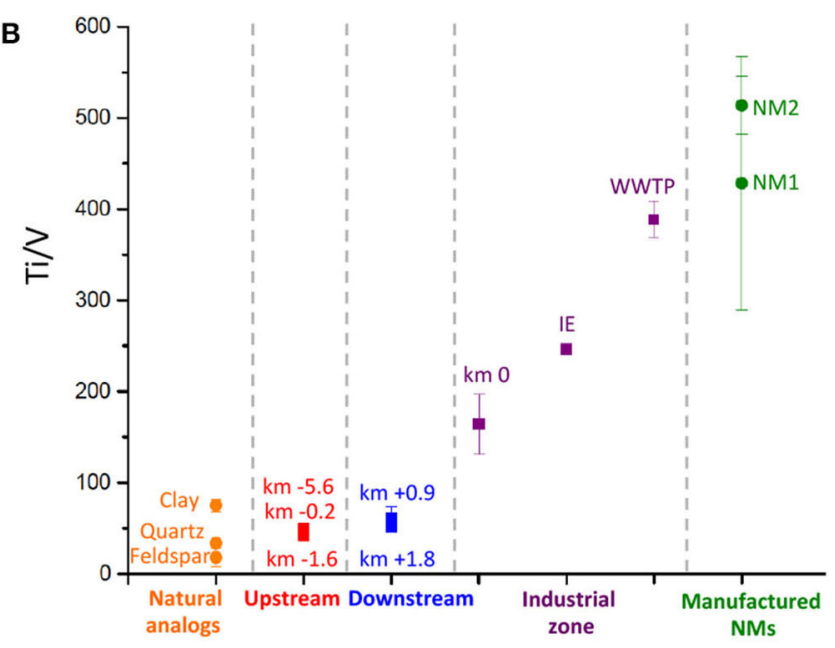

$\sum_{30} 40-$

$-1$

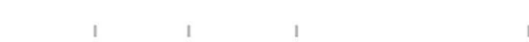

$T^{2}$

IM2

TNM1

1

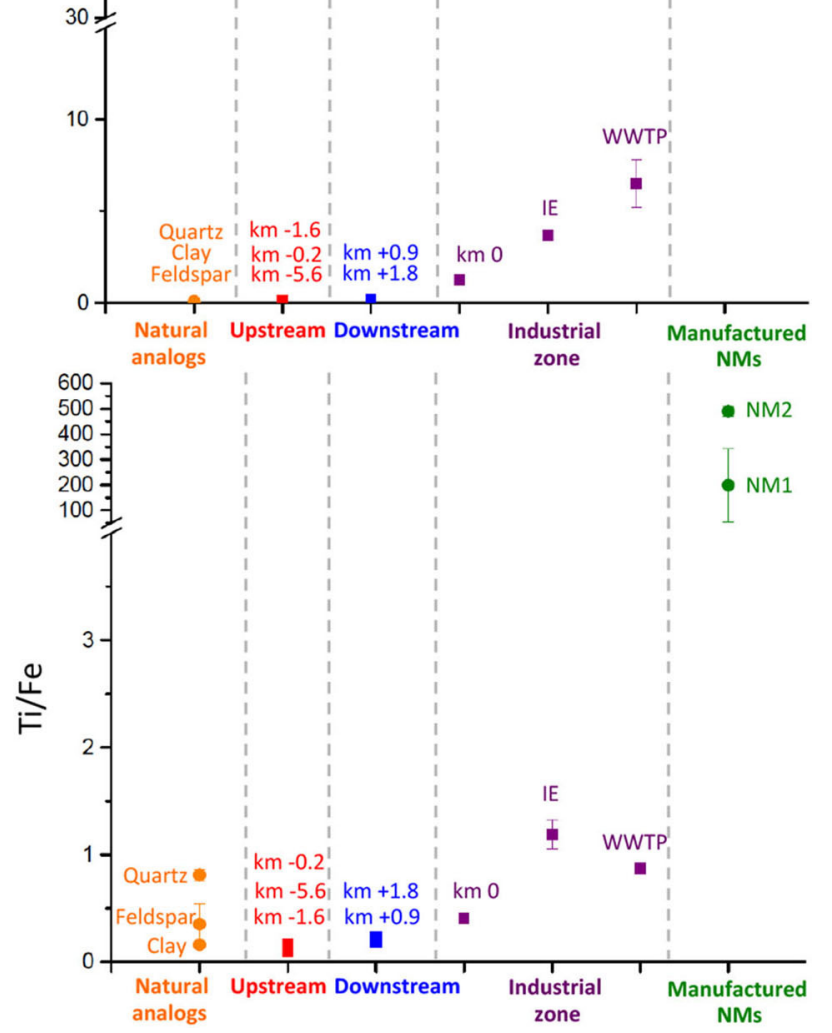

FIGURE 3 | Mineralogical and elemental analysis of sediments from October 2017: (A) XRD of fine fraction $(X<1 \mu \mathrm{m})$ and 1-250 $\mu \mathrm{m}$ fraction validating presence of anatase and rutile $\mathrm{TiO}_{2}$ in Industrial Effluent and WWTP (Full XRD spectra in Supporting Information Figure S3). (B) Ratios of Ti/X (X=V, Al, and Fe) concentrations of analogs (e.g., NM1, NM2, clay) and river sediment to differentiate between anthropogenic inputs and natural $\mathrm{TiO}_{2}$. IE, Industrial Effluent. Error bars represent replicate sample digestions of the same sample $(n=3)$. 
these $\mathrm{TiO}_{2}$ particles were anthropogenic or of natural origin. However, it must be considered that the comparison of $\mathrm{Ti} / \mathrm{X}$ ratios using bulk elemental analysis measurements is based on the assumption that the natural background is best represented by individual, multi-element Ti-containing particles and not just the presence of numerous different particle compositions (e.g., $\mathrm{Fe}_{\mathrm{x}} \mathrm{Al}_{\mathrm{y}} \mathrm{Ti}_{\mathrm{z}} \mathrm{O}_{\mathrm{a}}$ vs. $\mathrm{Fe}_{\mathrm{x}} \mathrm{O}_{\mathrm{y}}, \mathrm{TiO}_{2}$, and $\mathrm{Al}_{\mathrm{x}} \mathrm{O}_{\mathrm{y}}$ ). NM1 and NM2 exhibited $\mathrm{Ti} / \mathrm{V}, \mathrm{Ti} / \mathrm{Al}$, and $\mathrm{Ti} / \mathrm{Fe}$ ratios of $428-513,42-55$, and 199-490, respectively, in marked contrast to the ratios of 18$75,0.01-0.1$, and $0.16-0.81$ measured in natural feldspar, clay, and quartz analogs. The manufactured NMs contain minimal amounts of $\mathrm{V}, \mathrm{Al}$, and $\mathrm{Fe}$ compared to $\mathrm{Ti}$, which significantly increases the $\mathrm{Ti} / \mathrm{X}$ ratio. In contrast, the feldspar, clay, and quartz contain naturally present $\mathrm{V}, \mathrm{Al}$, and $\mathrm{Fe}$, resulting in a lower $\mathrm{Ti} / \mathrm{X}$ ratio. Considering the natural river samples, the canal sediments at the Industrial Effluent and WWTP discharge sites exhibited much higher $\mathrm{Ti} / \mathrm{X}$ ratios compared to the other sites. Specifically, $\mathrm{Ti} / \mathrm{V}, \mathrm{Ti} / \mathrm{Al}$, and $\mathrm{Ti} / \mathrm{Fe}$ ratios of 246-389, 3.7-6.5, and 0.87-1.19 were determined for the Industrial Effluent and WWTP sites whereas at $\mathrm{km}-5.6$ these same ratios were $49,0.12$, and 0.15 . The sediment at $\mathrm{km} 0$ (confluence of the industrial drainage canal and the river) was also characterized by elevated $\mathrm{Ti} / \mathrm{X}$ ratios compared to the other sites. Of the element ratios tested here, $\mathrm{Ti} / \mathrm{V}$ was the strongest indicator of anthropogenic Ti origin, due to a lower and less variable natural background of $\mathrm{V}$ compared to $\mathrm{Al}$ and $\mathrm{Fe}$, as well as the possibility of $\mathrm{Al}$ and Fe contamination from the industrial canal sites. In fact, the manufacturing plant uses ilmenite $\left(\mathrm{FeTiO}_{3}\right)$ for $\mathrm{TiO}_{2} \mathrm{NM}$ production and WWTPs are known to use Al- and Fe-based salts in their treatment processes (Liu et al., 2013). The elemental analysis results shown here are for the sediments collected in October 2017, but the same trends were revealed for the sediments collected in March 2018 (Figure S4).

While the $\mathrm{Ti} / \mathrm{X}$ ratios for the sediments at the Industrial Effluent and WWTP discharge sites, and at $\mathrm{km} 0$ were not as high as those of the pure $\mathrm{TiO}_{2} \mathrm{NMs}$, their significantly elevated values combined with the mineralogy determined by $\mathrm{XRD}$ support the anthropogenic and non-natural origin of the $\mathrm{TiO}_{2}$ in the surface sediment. In order to elucidate the potential sources (e.g., industrial drainage canal or river) of this long-term anthropogenic $\mathrm{TiO}_{2}$ sediment accumulation, the $\mathrm{Ti}$ concentrations in the surface waters were measured for each site.

\section{Real-Time $\mathrm{TiO}_{2}$ Occurrence in the Surface Waters}

The total Ti concentrations measured in the raw surface waters collected in October 2017 exhibited a similar trend to that observed in the sediments, with low Ti background levels (3.4$7.0 \mu \mathrm{g} / \mathrm{L})$ at $\mathrm{km}-5.6,-1.6$, and -0.2 , and significant increases in Ti at both the Industrial Effluent and WWTP sites, up to 133 and $260 \mu \mathrm{g} \mathrm{Ti} / \mathrm{L}$, respectively (Figure 4). Again, due to particle transport, $\mathrm{TiO}_{2}$ particles originating from the Industrial Effluent likely contributed to increased Ti concentrations at the WWTP site (Praetorius et al., 2012; Sani-Kast et al., 2015). Downstream of the drainage canal, Ti concentrations in the water column did not return to upstream background levels, even at $\mathrm{km}+1.8$ after the confluence, where the $\mathrm{Ti}$ concentration remained elevated $(56.6 \pm 8.6 \mu \mathrm{g} / \mathrm{L})$. This finding is in support of river fate model predictions that have indicated that $\mathrm{TiO}_{2} \mathrm{NMs}$ can be transported several kilometers before settling into the sediment.

In March 2018, the Ti concentrations in the surface waters did not show any evolution along the industrial drainage canal or the river. At every sampling site, the Ti concentrations were comparable to that measured upstream at $\mathrm{km}-5.6(4.9 \pm 1.4$ $\mu \mathrm{g} / \mathrm{L}$ ), even at the Industrial Effluent and WWTP discharge sites, where the measured concentrations were $3.4 \pm 2.8$ and 1.8 $\pm 0.5 \mu \mathrm{g} / \mathrm{L}$, respectively. The disparate differences in total $\mathrm{Ti}$ detected in the surface waters between the two sampling dates could be the result of changes in waste management by the nanomaterial manufacturer (e.g., discharge), variations in canal flow, or due to seasonal dilution effects (e.g., rain or snowmelt) (Thompson, 1982; Carling et al., 2015). Indeed, changes in cation concentrations (Table S1) and the river outflow at $\mathrm{km}-5.6$ between October 2017 and March 2018 suggest some dilution effects in the river. In October 2017 at $\mathrm{km}-5.6$, the river outflow was $0.98 \pm 0.01 \mathrm{~m}^{3} \cdot \mathrm{s}^{-1}$ and $\mathrm{Na}^{+}$and $\mathrm{Ca}^{2+}$ concentrations were 0.497 and $0.207 \mathrm{mM}$, respectively, whereas in March 2018, the river outflow was $\sim 5 \times$ higher at $4.89 \pm 0.01 \mathrm{~m}^{3} . \mathrm{s}^{-1}$ and the cation concentrations were lower $\left(0.294 \mathrm{mM} \mathrm{Na}^{+}\right.$and $0.157 \mathrm{mM} \mathrm{Ca}^{2+}$ ). However, the low Ti concentrations detected in the surface waters at the Industrial Effluent and WWTP sites in March 2018 were more likely related to industrial waste management and differences in discharge since $\mathrm{Na}^{+}(0.308-$ $6.26 \mathrm{mM})$ and $\mathrm{Ca}^{2+}(0.204-0.219 \mathrm{mM})$ concentrations in March 2018 were either similar or higher than in October 2017 (0.5$2.07 \mathrm{mM} \mathrm{Na}^{+}$and $0.226-0.284 \mathrm{mM} \mathrm{Ca}^{2+}$ ) and water depth was comparable between the two seasons.

Similar to the analysis conducted for the sediments, $\mathrm{Ti} / \mathrm{X}$ ratios $(\mathrm{X}=\mathrm{V}, \mathrm{Al}, \mathrm{Fe})$ were also calculated for the surface waters collected in October 2017 to discriminate between an anthropogenic vs. natural origin of the detected $\mathrm{Ti}$ (Figure 5). The $\mathrm{Ti} / \mathrm{X}$ ratios were not calculated for the surface waters from March 2018 since no significant $\mathrm{Ti}$ was detected. The total element concentrations in the surface waters can be found in Table S3. At the Industrial Effluent, the determined $\mathrm{Ti} / \mathrm{V}, \mathrm{Ti} / \mathrm{Al}$, and $\mathrm{Ti} / \mathrm{Fe}$ ratios were $\sim 14 \times$ higher (ratios of $149,1.13$, and 1.27 , respectively) than the ratios measured for the upstream sites (5-10, 0.05-0.08, and 0.08-0.09, respectively). Moving along the industrial drainage canal, Ti/X ratios in the WWTP surface water also remained elevated $(4.5-15 \times)$ compared to those upstream. In contrast to the sediments where $\mathrm{Ti} / \mathrm{X}$ ratios downstream of $\mathrm{km} 0$ were similar to those upstream as a result of minimal anthropogenic $\mathrm{Ti}$ accumulation, in the surface waters $\mathrm{Ti} / \mathrm{V}, \mathrm{Ti} / \mathrm{Al}$, and $\mathrm{Ti} / \mathrm{Fe}$ ratios remained elevated at $\mathrm{km} 0,+0.9$, and $+1.8(31-$ $51,0.14-0.32$, and $0.19-0.33$ ). These complementary analyses of the surface water $\mathrm{Ti} / \mathrm{X}$ ratios confirm the anthropogenic Ti emission from the Industrial Effluent and WWTP sites in October 2017. This demonstrates that the Ti measured in the surface waters downstream of the confluence resulted from the transport of anthropogenic material, not just the re-suspension of natural $\mathrm{Ti}$ in the sediment.

Using this data, the contribution of anthropogenic $\mathrm{TiO}_{2}$ to the total $\mathrm{Ti}$ in the surface waters collected in October 2017 was 


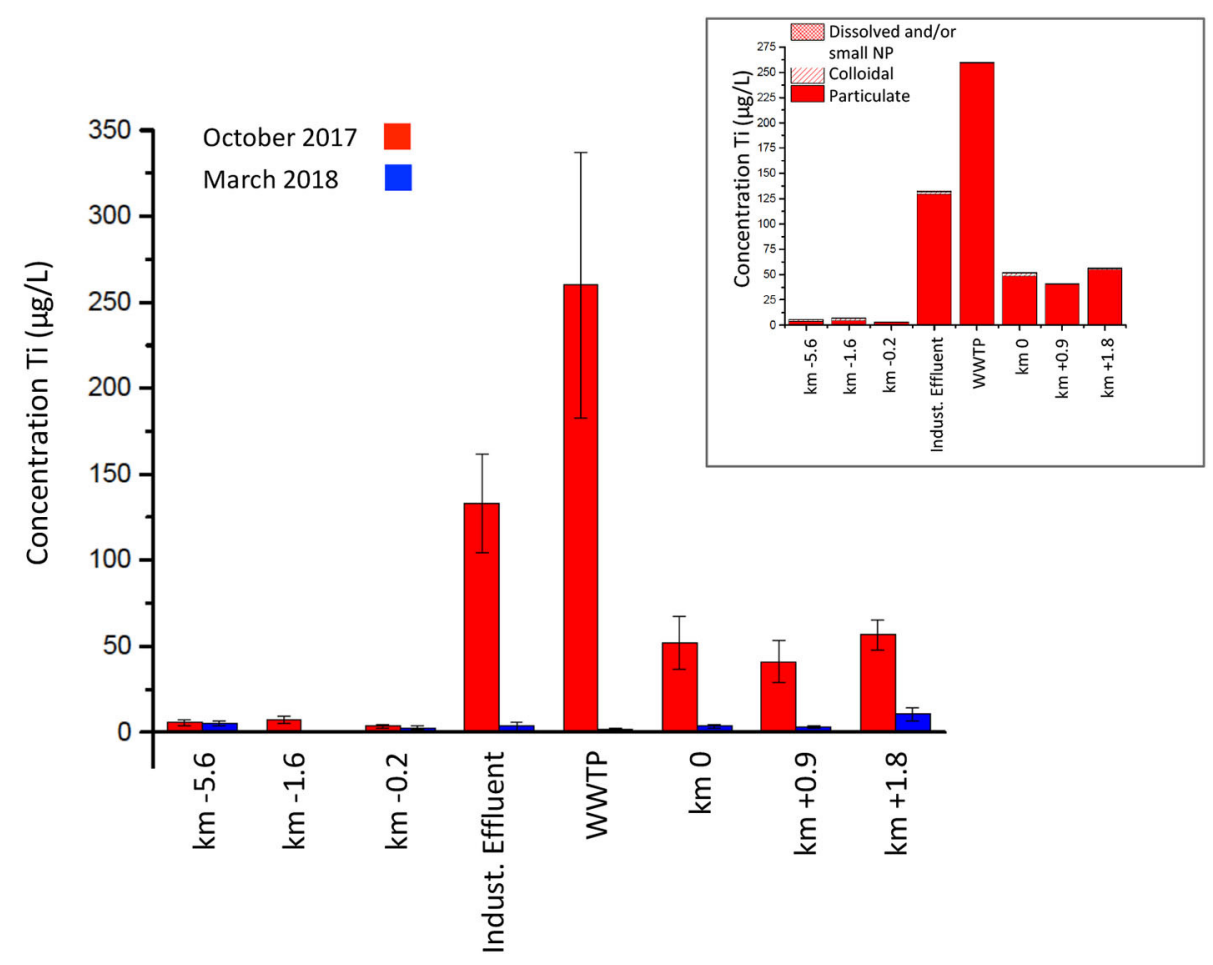

FIGURE 4 | Total Ti concentrations $(\mu \mathrm{g} / \mathrm{L})$ in raw surface waters. Inset: Ti concentrations $(\mu \mathrm{g} / \mathrm{L})$ measured in dissolved and/or nanoparticulate $(\mathrm{NP})(<0.02 \mu \mathrm{m})$ fraction and Ti concentrations $(\mu \mathrm{g} / \mathrm{L})$ calculated for colloidal $(0.02-0.20 \mu \mathrm{m})$ and particulate $(>0.20 \mu \mathrm{m})$ fractions for October 2017 samples. Error bars represent replicate sample digestions of the same sample $(n=3)$.

estimated using Equation (1), as previously detailed in Loosli et al. (2019) These estimations are based on the assumption that all Ti measured above the background was in the form of pure $\mathrm{TiO}_{2}$.

$$
\left[\mathrm{TiO}_{2}\right]_{\text {anthropogenic }}=\frac{\mathrm{TiO}_{2 \mathrm{MM}}}{\mathrm{Ti}_{\mathrm{MM}}}\left[\mathrm{Ti}_{\text {sample }}-\mathrm{V}_{\text {sample }}\left(\frac{\mathrm{Ti}}{\mathrm{V}}\right)_{\text {background }}\right]
$$

where $\left[\mathrm{TiO}_{2}\right]_{\text {anthropogenic }}$ is the estimated concentration of anthropogenic $\mathrm{TiO}_{2}, \mathrm{Ti}_{\mathrm{MM}}$ and $\mathrm{TiO}_{2 \mathrm{MM}}$ are the molar masses (MM) of $\mathrm{Ti}$ and $\mathrm{TiO}_{2}, \mathrm{Ti}_{\text {sample }}$ and $\mathrm{V}_{\text {sample }}$ are the total mass concentrations, and $\mathrm{Ti} / \mathrm{V}$ is the molar mass ratio of $\mathrm{Ti}$ to $\mathrm{V}$. The background $\mathrm{Ti} / \mathrm{V}$ ratio was calculated using the average $\mathrm{Ti} / \mathrm{V}$ ratios measured at the three upstream sampling locations (i.e., $\mathrm{km}-5.6,-1.6,-0.2)$. For the Industrial Effluent and WWTP sites along the drainage canal, estimated $\mathrm{TiO}_{2 \text { anthropogenic }}$ concentrations were 209 and $411 \mu \mathrm{g} / \mathrm{L}$, representing 94 and $95 \%$ of the measured total $\mathrm{Ti}$ in the surface water, respectively. As expected, the estimated $\mathrm{TiO}_{2 \text { anthropogenic concentrations }}$ downstream at the $\mathrm{km} 0$ and $\mathrm{km}+1.8$ sites were lower at 73 and $71 \mu \mathrm{g} / \mathrm{L}$, representing 85 and $76 \%$ of the measured total Ti in the surface water, respectively.

Beyond validating the origin of the $\mathrm{TiO}_{2}$ release, evaluating the size of the emitted particles is crucial for predicting their transport, fate, and potential toxicity. The October 2017 surface waters were filtered to look for the presence of $\mathrm{TiO}_{2}$ in the particulate $(>0.20 \mu \mathrm{m})$, colloidal $(0.02-0.20 \mu \mathrm{m})$, and dissolved and/or small nanoparticulate $(<0.02 \mu \mathrm{m})$ fractions. Filtration and elemental analysis were also performed for the March 2018 samples, but due to low Ti concentrations in the raw surface waters, $\mathrm{Ti}$ in the filtrates was below $2 \mathrm{nM}$ and not quantifiable (results not shown). As shown in the Figure 4 inset, for the $\mathrm{TiO}_{2}$ emitted from the Industrial Effluent and WWTP and then transported to the confluence at $\mathrm{km} 0$, the majority of $\mathrm{Ti}$ was in the particulate form (98.6, 99.8, and 94\% for the three sites, respectively), with a small contribution from the colloidal and dissolved and/or nanoparticulate fractions (0.2-6\%). Specifically, $\mathrm{Ti}$ concentrations in the colloidal fraction were calculated to be $1.8,0.4$, and $3.1 \mu \mathrm{g} / \mathrm{L}$ for the Industrial Effluent, WWTP, and $\mathrm{km} 0$ sites, whereas $\mathrm{Ti}$ concentrations measured in the dissolved/nanoparticulate fraction were $1.5,0.3$, and $0.4 \mathrm{ug} / \mathrm{L}$ for the respective sites. However, caution must be taken in interpreting these results, as previous work has shown that $\mathrm{TiO}_{2}$ NMs can homo- and hetero- aggregate under river water conditions to form $\mu \mathrm{m}$-sized aggregates (Loosli et al., 2013; Labille et al., 2015; Adam et al., 2016). Thus, the elemental analysis of the filtrates performed here cannot be used to distinguish between the presence of primary $\mathrm{TiO}_{2}$ particles $>0.20 \mu \mathrm{m}$ and aggregates containing primary $\mathrm{TiO}_{2}$ particles $<0.20 \mu \mathrm{m}$.

Scanning electron microscopy (SEM) was used to visualize potential anthropogenic $\mathrm{TiO}_{2}$ particles collected on $0.20 \mu \mathrm{m}$ filter membranes from the Industrial Effluent and WWTP surface 


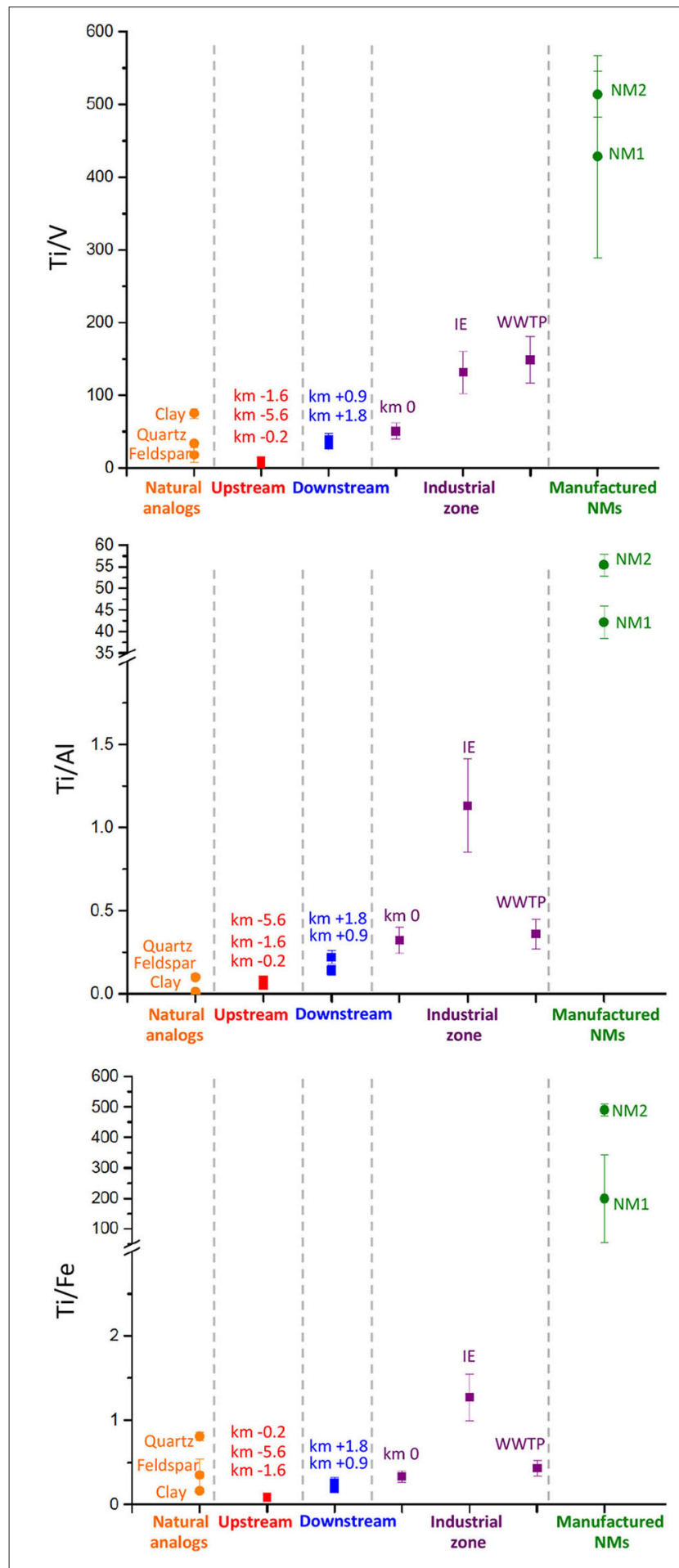

FIGURE 5 | Elemental analysis of surface waters from October 2017: Ratios of $\mathrm{Ti} / \mathrm{X}(\mathrm{X}=\mathrm{V}, \mathrm{Al}$, and $\mathrm{Fe})$ showing anthropogenic inputs. IE, Industrial Effluent. Error bars represent replicate sample digestions of the same sample $(n=3)$.

waters in October 2017. Although such an analysis remains challenging due to the low amount of $\mathrm{Ti}$ and considerable difficulty in providing statistically relevant data, it provided information on the primary particle size and morphology.
The resulting SEM images revealed the presence of clusters of spherical nanomaterials in the waters collected from the Industrial Effluent and WWTP, with a shape and size consistent of $\mathrm{TiO}_{2}$ synthesized for industrial and commercial applications (Figure 6) (Westerhoff et al., 2011). For the Industrial Effluent (Figure 6A), the nanomaterials in the imaged cluster had a primary particle size of $50 \pm 13 \mathrm{~nm}$ (1 image, $n=11$ particles), whereas for the WWTP (Figure 6B), the primary particle size was larger at $174 \pm 43 \mathrm{~nm}$ ( 1 image, $n=8$ particles). Furthermore, both EDS spectra exhibited Ti $\mathrm{K}$ and $\mathrm{O} \mathrm{K}$ peaks, confirming that the particles were $\mathrm{TiO}_{2}$. Of note, the presence of some $\mathrm{P}$ and $\mathrm{Fe}$ can be attributed to the surrounding environment, while the large $\mathrm{Al}$ signal resulted from the aluminum oxide membrane filter and the SEM pin stub. Additional SEM images and EDS spectra of other regions on the same $0.20 \mu \mathrm{m}$ filter membranes also showed clusters of spherical $\mathrm{TiO}_{2}$ nanomaterials, with primary particle sizes of $\sim 50-150 \mathrm{~nm}$ (Figures S5-S7).

While Ti elemental analysis of the surface water fractions suggested that $>94 \%$ of the emitted $\mathrm{TiO}_{2}$ particles were $>0.20 \mu \mathrm{m}$, primary $\mathrm{TiO}_{2}$ particles observed with SEM were $<0.20 \mu \mathrm{m}$, and should have passed through the $0.20 \mu \mathrm{m}$ membrane pores during filtration. These results indicate that the anthropogenic $\mathrm{TiO}_{2}$ in the canal waters likely exists as aggregates of nanomaterials, at least in the Industrial Effluent. However, without further investigation it is not possible to discriminate between aggregates of fused $\mathrm{TiO}_{2}$ nanomaterials formed during manufacturing from individual $\mathrm{TiO}_{2}$ nanomaterials incorporated in homo- or hetero-aggregates formed in the canal waters under favorable ionic strength conditions (Loosli et al., 2013; Adam et al., 2016; Ilina et al., 2017; Slomberg et al., 2019). The formation of $\mathrm{TiO}_{2} \mathrm{NM}$ homo-aggregates over hetero-aggregates in the canal waters would only be probable if the NMs were present at a far greater concentration compared to that of natural colloids (Figure S8).

The significant differences in size of the $\mathrm{TiO}_{2}$ particles collected at the Industrial Effluent and WWTP in October 2017 may result from temporal variations in particle manufacturing (production of nanomaterial and pigment), waste treatment, and effluent emissions. Furthermore, the disparity between the particles collected at the Industrial Effluent and the WWTP is coherent with the fact that the effluents from the NM manufacturing plant and the urban WWTP are unlikely to have the same composition. Any NMs present in the industrial effluent would be presumably composed of a mixture of unaged anatase and rutile $\mathrm{TiO}_{2}$ based on plant production schedules, while those released in WWTP effluents most likely have a different origin and come from aged by-products of paints and personal care products (e.g., toothpaste, cosmetics) (Westerhoff et al., 2011).

\section{Environmental Exposure Implications: $\mathrm{TiO}_{2}$ Nanomaterial Release and Transport}

The aggregation state of engineered nanomaterials in aqueous environments is a crucial parameter for predicting their residence time in the water column, their potential accumulation in the 

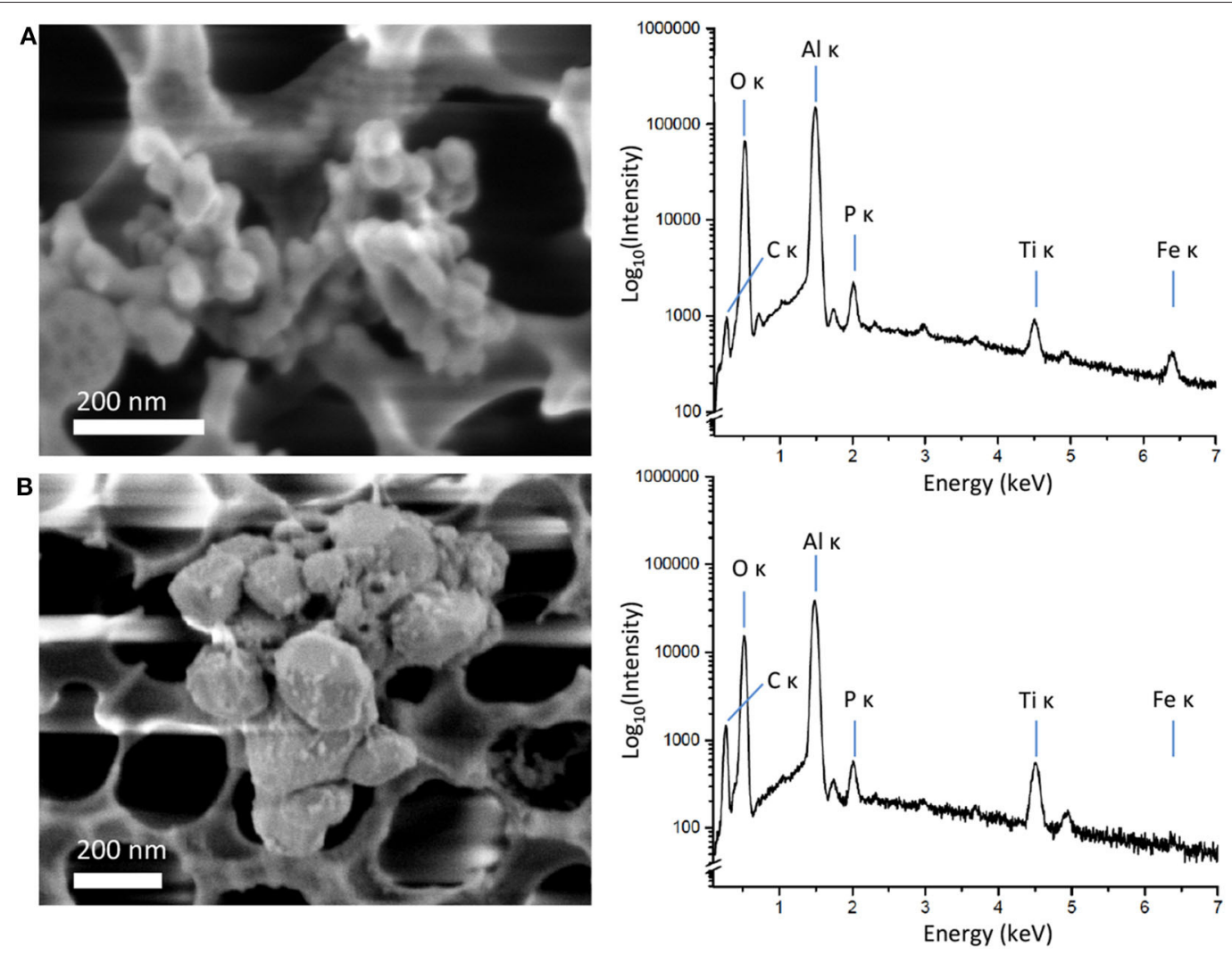

FIGURE 6 | SEM images (left) and corresponding EDS spectra (right) of particles recovered on 0.20 $\mu \mathrm{m}$ filters from (A) Industrial Effluent and (B) WWTP in October 2017. Some charging features present in SEM images as a result of no coating being applied to samples.

sediment layer, and determining which organisms are at risk of exposure. In addition to the $\mathrm{TiO}_{2} \mathrm{NM}$ clusters observed with SEM (Figure 6), the distributions of the measured $\mathrm{Ti}$ concentrations in the sediments and surface water fractions along the industrial drainage canal and river are also in support of the presence of $\mathrm{TiO}_{2} \mathrm{NM}$ aggregates that sediment close to the emission source. As evidenced in Figure 2, the $\mathrm{TiO}_{2}$ NMs accumulate in the canal sediment close to the sources of the Industrial Effluent and WWTP discharge. Downstream of the confluence, the measured NM accumulation was not significant, with the $\mathrm{TiO}_{2}$ detected at $\mathrm{km}+1.8$ representing only $\sim 2 \%$ of that detected in the canal sediments near the two sources. However, due to the non-negligible $\mathrm{TiO}_{2}$ background in the sediments $(\sim 5 \mathrm{mg} / \mathrm{kg})$, minor changes in accumulation can be difficult to verify with elemental analysis. The presence and accumulation of anatase $\mathrm{TiO}_{2}$ in sediments at $\mathrm{km}+1.8$ were thus confirmed by complementary XRD analysis (Figure S3), further supporting that there is some $\mathrm{TiO}_{2} \mathrm{NM}$ transport downstream even though the majority of $\mathrm{TiO}_{2}$ sedimentation occurs near the emission source. We also evaluated the potential of epilithic organisms to accumulate $\mathrm{Ti}$ by scraping them from sedimentary river rocks and analyzing them for $\mathrm{Ti}$ concentration. These epilithic organisms (and possible associated sediment remaining after rinsing) from both October 2017 and March 2018 showed signs of significant $\mathrm{Ti}$ accumulation near the source, with concentrations of 3.3-5.8, 15.4-53.6, and $9.8-11.8 \mathrm{mg} \mathrm{Ti} / \mathrm{kg}$ (dry weight) at $\mathrm{km}-5.6$, 0 , and +1.8 . The Ti/V molar ratios of 53-68, 144-224, and 38-61 in the epilithic organisms at $\mathrm{km}-5.6,0$, and +1.8 also support an accumulation of anthropogenic $\mathrm{Ti}$ at $\mathrm{km} 0$. As primary producers, these epilithic organisms represent the bottom of the trophic chain in the river ecosystem. Their $\mathrm{TiO}_{2}$ accumulation thus provides a potential exposure pathway for primary consumers that feed on the sediments and subsequent entry into the food web.

Here, the canal and river sediments were a strong indicator of long-term NM accumulation, with similar $\mathrm{TiO}_{2}$ concentrations observed for October 2017 and March 2018 along the various sites, including the Industrial Effluent, WWTP, and $\mathrm{km} 0$. Yet, the sediment $\mathrm{TiO}_{2}$ concentrations were not sensitive enough to provide information on real-time occurrence due to the difficulty in distinguishing small changes from a high background. The surface waters, having a low Ti background (3.4-7.0 $\mu \mathrm{g} \mathrm{Ti} / \mathrm{L}$ ), offered a better indication of NM pulse release and transport mechanisms. As previously detailed, Ti concentrations in surface waters in October 2017 and March 2018 varied significantly (Figure 4), suggesting that NM emission in the canal was not constant and that environmental conditions (e.g., canal and river flow, seasonal dilution) may also play a role in NM detection. In October 2017, more significant transport was observed in the 
surface water compared to what was revealed by the sediments. Downstream of the confluence at $\mathrm{km}+1.8,20-40 \%$ of the $\mathrm{TiO}_{2}$ detected at the emission sources remained in suspension. Thus, the processes of NM aggregation, sedimentation, and transport would likely continue further downstream of $\mathrm{km}+1.8$. Indeed, $\mathrm{TiO}_{2} \mathrm{NM}$ fate model predictions have found that significant downstream transport is possible (Praetorius et al., 2012; SaniKast et al., 2015).

\section{CONCLUSIONS}

The thorough characterization of the surface water and sediment in a river next to a $\mathrm{TiO}_{2} \mathrm{NM}$ manufacturing plant highlighted both the presence and transport of anthropogenic $\mathrm{TiO}_{2} \mathrm{NMs}$ in the river ecosystem. Overall, the anthropogenic NMs exhibited rapid sedimentation near the $\mathrm{TiO}_{2}$ emission source, but transport was still detected $\sim 2 \mathrm{~km}$ downstream. It was also evidenced that the anthropogenic Ti transport occurred mainly via the particulate fraction $(>0.20 \mu \mathrm{m})$ as aggregates in the water column. Emissions into the surface waters were likely transient due to industrial/WWTP management, but differences in measured Ti concentrations could also result from contrasting seasonal conditions in October 2017 and March 2018. Despite differences in real-time surface water concentrations, longterm anthropogenic $\mathrm{TiO}_{2}$ accumulation was observed in the sediments near the source of the treated industrial effluents, but further work is needed to confirm the presence and distribution of $\mathrm{TiO}_{2} \mathrm{NMs}$ in these sediments. Future studies should also include additional sampling sites near the emission sources and downstream to provide a more detailed and spatially resolved understanding of the $\mathrm{TiO}_{2} \mathrm{NM}$ transport and sedimentation. Sampling over several time periods will also be crucial for evaluating the transient nature of the $\mathrm{TiO}_{2} \mathrm{NMs}$ detected in the surface waters. The influence of these NMs on river organisms should also be further evaluated, investigating the effects of the $\mathrm{TiO}_{2} \mathrm{NMs}$ on several organisms in the trophic chain (primary producers and consumers) using relevant concentrations and considering pulse vs. chronic exposures.

\section{REFERENCES}

Adam, V., Loyaux-Lawniczak, S., Labille, J., Galindo, C., del Nero, M., Gangloff, S., et al. (2016). Aggregation behaviour of $\mathrm{TiO}_{2}$ nanoparticles in natural river water. J. Nanopart. Res. 18:13. doi: 10.1007/s11051-015-3319-4

Auffan, M., Liu, W., Brousset, L., Scifo, L., Pariat, A., Sanles, M., et al. (2018). Environmental exposure of a simulated pond ecosystem to a $\mathrm{CuO}$ nanoparticlebased wood stain throughout its life cycle. Environ. Sci. Nano 5, 2579-2589. doi: $10.1039 / \mathrm{C} 8 \mathrm{EN} 00712 \mathrm{H}$

Baalousha, M., Wang, J., Nabi, M. M., Loosli, F., Valenca, R., Mohanty, S. K., et al. (2020). Stormwater green infrastructures retain high concentrations of $\mathrm{TiO} 2$ engineered (nano)-particles. J. Hazard Mater. 392:122335. doi: 10.1016/j.jhazmat.2020.122335

Botta, C., Labille, J., Auffan, M., Borschneck, D., Miche, H., Cabié, M., et al. (2011). $\mathrm{TiO}_{2}$-based nanoparticles released in water from commercialized sunscreens in a life-cycle perspective: structures and quantities. Environ. Pollut. 159, 1543-1550. doi: 10.1016/j.envpol.2011.03.003

Carling, G. T., Tingey, D. G., Fernandez, D. P., Nelson, S. T., Aanderud, Z. T., Goodsell, T. H., et al. (2015). Evaluating natural and anthropogenic trace

\section{DATA AVAILABILITY STATEMENT}

The raw data supporting the conclusions of this article will be made available by the authors, without undue reservation.

\section{AUTHOR CONTRIBUTIONS}

MA and JR collected samples along the river and industrial drainage canal. DS prepared and conducted elemental analysis of the water, sediment, and epilithic organism samples with the help of NG and BA. DS and DB prepared and analyzed sediment samples with XRD. DS, MA, AC, and JR prepared and analyzed filter membranes with SEM. DS, MA, AC, DB, OA-C, and JR contributed to the interpretation of data. DS, MA, AC, OA-C, and JR contributed to the writing of the manuscript. All authors contributed to the article and approved the submitted version.

\section{ACKNOWLEDGMENTS}

This work was financed in part by the French Agency for the Environmental and Energetic Management (ADEME) under the contract number 1581C0027 called NANO-IDENT, funded by the 2015 CORTEA call. This work is a contribution to the OSU-Institut Pythéas, and to the Labex Serenade program (no. ANR-11-LABX-0064) funded by the Investissements d'Avenir program of the French National Research Agency (ANR) through the A*MIDEX project (no. ANR-11-IDEX-000102). The authors acknowledge the CNRS for the funding of the IRP iNOVE.

\section{SUPPLEMENTARY MATERIAL}

The Supplementary Material for this article can be found online at: https://www.frontiersin.org/articles/10.3389/fenvs. 2020.00076/full\#supplementary-material

element inputs along an alpine to urban gradient in the Provo River, Utah, USA. Appl. Geochem. 63, 398-412. doi: 10.1016/j.apgeochem.2015.10.005

de Klein, J. J., Quik, J. T., Bäuerlein, P. S., and Koelmans, A. A. (2016). Towards validation of the NanoDUFLOW nanoparticle fate model for the river Dommel, The Netherlands. Environ. Sci. Nano 3, 434-441. doi: 10.1039/C5EN0 0270B

Fazio, S., Guzman, J., Colomer, M., Salomoni, A., and Moreno, R. (2008). Colloidal stability of nanosized titania aqueous suspensions. J. Eur. Ceram. Soc. 28, 2171-2176. doi: 10.1016/j.jeurceramsoc.2008.02.017

Gondikas, A., von der Kammer, F., Kaegi, R., Borovinskaya, O., Neubauer, E., Navratilova, J., et al. (2018). Where is the nano? Analytical approaches for the detection and quantification of $\mathrm{TiO}_{2}$ engineered nanoparticles in surface waters. Environ. Sci. Nano 5, 313-326. doi: 10.1039/C7EN00952F

Gondikas, A. P., Kammer, F., Reed, R. B., Wagner, S., Ranville, J. F., and Hofmann, T. (2017). Release of TiO2 nanoparticles from sunscreens into surface waters: a one-year survey at the old Danube recreational Lake. Environ. Sci. Technol. 48, 5415-5422. doi: 10.1021/es405596y

Hadioui, M., Knapp, G., Azimzada, A., Jreije, I., Frechette-Viens, L., and Wilkinson, K. J. (2019). Lowering the size detection limits of $\mathrm{Ag}$ and $\mathrm{TiO}_{2}$ 
nanoparticles by single particle ICP-MS. Anal. Chem. 91, 13275-13284. doi: 10.1021/acs.analchem.9b04007

Hissler, C., and Probst, J.-L. (2006). Chlor-alkali industrial contamination and riverine transport of mercury: distribution and partitioning of mercury between water, suspended matter, and bottom sediment of the Thur River, France. Appl. Geochem. 21, 1837-1854. doi: 10.1016/j.apgeochem.2006.08.002

Ilina, S. M., Ollivier, P., Slomberg, D., Baran, N., Pariat, A., Devau, N., et al. (2017). Investigations into titanium dioxide nanoparticle and pesticide interactions in aqueous environments. Environ. Sci. Nano 4, 2055-2065. doi: 10.1039/C7EN00445A

Iswarya, V., Bhuvaneshwari, M., Alex, S. A., Iyer, S., Chaudhuri, G., Chandrasekaran, P. T., et al. (2015). Combined toxicity of two crystalline phases (anatase and rutile) of Titania nanoparticles towards freshwater microalgae: Chlorella sp. Aquat. Toxicol. 161, 154-169. doi: 10.1016/j.aquatox.2015.02.006

Johnson, A. C., Bowes, M. J., Crossley, A., Jarvie, H. P., Jurkschat, K., Jürgens, M. D., et al. (2011). An assessment of the fate, behaviour and environmental risk associated with sunscreen $\mathrm{TiO}_{2}$ nanoparticles in UK field scenarios. Sci. Tot. Environ. 409, 2503-2510. doi: 10.1016/j.scitotenv.2011.03.040

Labille, J., Harns, C., Bottero, J.-Y., and Brant, J. (2015). Heteroaggregation of titanium dioxide nanoparticles with natural clay colloids under environmentally relevant conditions. Environ. Sci. Technol. 48, 10690-10698. doi: $10.1021 /$ es501655v

Labille, J., Slomberg, D., Catalano, R., Robert, S., Apers-Tremelo, M.-L., Boudenne, J.-L., et al. (2019). Assessing UV filter inputs into beach waters during recreational activity: a field study of three French Mediterranean beaches from consumer survey to water analysis. Sci. Tot. Environ. 2019:136010. doi: 10.1016/j.scitotenv.2019.136010

Liu, X., Chen, G., and Su, C. (2011). Effects of material properties on sedimentation and aggregation of titanium dioxide nanoparticles of anatase and rutile in the aqueous phase. J. Coll. Int. Sci. 363, 84-91. doi: 10.1016/j.jcis.2011.06.085

Liu, Y., Zhang, W., Yang, X., Xiao, P., Wang, D., and Song, Y. (2013). Advanced treatment of effluent from municipal WWTP with different metal salt coagulants: contaminants treatability and floc properties. Sep. Purif. Technol. 120, 123-128. doi: 10.1016/j.seppur.2013.09.046

Loosli, F., Le Coustumer, P., and Stoll, S. (2013). $\mathrm{TiO}_{2}$ nanoparticles aggregation and disaggregation in presence of alginate and Suwannee River humic acids: $\mathrm{pH}$ and concentration effects on nanoparticle stability. Water Res. 47, 6052-6063. doi: 10.1016/j.watres.2013.07.021

Loosli, F., Wang, J., Rothenberg, S., Bizimis, M., Winkler, C., Borovinskaya, O., et al. (2019). Sewage spills are a major source of titanium dioxide engineered (nano)-particle release into the environment. Environ. Sci. Nano 6, 763-777. doi: 10.1039/C8EN01376D

Markus, A., Krystek, P., Tromp, P., Parsons, J., Roex, E., de Voogt, P., et al. (2018). Determination of metal-based nanoparticles in the river Dommel in the Netherlands via ultrafiltration, HR-ICP-MS and SEM. Sci. Tot. Environ. 631, 485-495. doi: 10.1016/j.scitotenv.2018.03.007

Mitrano, D. M., Motellier, S., Clavaguera, S., and Nowack, B. (2015). Review of nanomaterial aging and transformations through the life cycle of nano-enhanced products. Environ. Int. 77, 132-147. doi: 10.1016/j.envint.2015.01.013

Nowack, B., Ranville, J. F., Diamond, S., Gallego-Urrea, J. A., Metcalfe, C., Rose, J., et al. (2012). Potential scenarios for nanomaterial release and subsequent alteration in the environment. Environ. Toxicol. Chem. 31, 50-59. doi: $10.1002 /$ etc. 726

Peters, R. J., van Bemmel, G., Milani, N. B., den Hertog, G. C., Undas, A. K., van der Lee, M., et al. (2018). Detection of nanoparticles in Dutch surface waters. Sci. Tot. Environ. 621, 210-218. doi: 10.1016/j.scitotenv.2017.11.238

Piccinno, F., Gottschalk, F., Seeger, S., and Nowack, B. (2012). Industrial production quantities and uses of ten engineered nanomaterials in Europe and the world. J. Nanopart. Res. 14:1109. doi: 10.1007/s11051-012-1109-9

Praetorius, A., Scheringer, M., and Hungerbühler, K. (2012). Development of environmental fate models for engineered nanoparticles-A case study of
$\mathrm{TiO}_{2}$ nanoparticles in the Rhine River. Environ. Sci. Technol. 46, 6705-6713. doi: 10.1021/es204530n

Reed, R., Martin, D., Bednar, A., Montaño, M., Westerhoff, P., and Ranville, J. (2017). Multi-day diurnal measurements of Ti-containing nanoparticle and organic sunscreen chemical release during recreational use of a natural surface water. Environ. Sci. Nano 4, 69-77. doi: 10.1039/C6EN00283H

Rubey, W. W. (1933). Settling velocity of gravel, sand, and silt particles. Am. J. Sci.25, 325-338. doi: 10.2475/ajs.s5-25.148.325

Sani-Kast, N., Scheringer, M., Slomberg, D., Labille, J., Praetorius, A., Ollivier, P., et al. (2015). Addressing the complexity of water chemistry in environmental fate modeling for engineered nanoparticles. Sci. Tot. Environ. 535, 150-159. doi: 10.1016/j.scitotenv.2014.12.025

Scifo, L., Chaurand, P., Bossa, N., Avellan, A., Auffan, M., Masion, A., et al. (2018). Non-linear release dynamics for $\mathrm{CeO}_{2}$ nanomaterial embedded in a protective wood stain, due to matrix photo-degradation. Environ. Pollut. 241, 182-193. doi: 10.1016/j.envpol.2018.05.045

Slomberg, D. L., Ollivier, P., Miche, H., Angeletti, B., Bruchet, A., Philibert, M., et al. (2019). Nanoparticle stability in lake water shaped by natural organic matter properties and presence of particulate matter. Sci. Tot. Environ. 656, 338-346. doi: 10.1016/j.scitotenv.2018.11.279

Sun, T. Y., Gottschalk, F., Hungerbühler, K., and Nowack, B. (2014). Comprehensive probabilistic modelling of environmental emissions of engineered nanomaterials. Environ. Pollut. 185, 69-76. doi: 10.1016/j.envpol.2013.10.004

Swanson, H. E., McMurdie, H. F., Morris, M. C., and Evans, E. H. (1969). Standard X-Ray Diffraction Powder Patterns: Data for 81 Substances. Washington, DC: National Bureau of Standards. doi: 10.6028/NBS.MONO.25-7

Thompson, M. E. (1982). "The cation denudation rate as a quantitative index of sensitivity of eastern Canadian rivers to acidic atmospheric precipitation," in Long-Range Transport of Airborne Pollutants, ed H. C. Martin (Dordrecht: Springer), 215-226. doi: 10.1007/978-94-009-7966-6_16

Vance, M. E., Kuiken, T., Vejerano, E. P., McGinnis, S. P., Hochella, M. F. Jr., Rejeski, D., et al. (2015). Nanotechnology in the real world: Redeveloping the nanomaterial consumer products inventory. Beilstein J. Nanotechnol. 6, 1769-1780. doi: 10.3762/bjnano.6.181

Von der Kammer, F., Ferguson, P. L., Holden, P. A., Masion, A., Rogers, K. R., Klaine, S. J.; et al. (2012). Analysis of engineered nanomaterials in complex matrices (environment and biota): general considerations and conceptual case studies. Environ. Toxicol. Chem. 31, 32-49. doi: 10.1002/etc.723

Von der Kammer, F., Legros, S., Hofmann, T., Larsen, E. H., and Loeschner, K. (2011).Separation and characterization of nanoparticles in complex food and environmental samples by field-flow fractionation. Trends Anal. Chem. 30, 425-436. doi: 10.1016/j.trac.2010.11.012

Wang, J., Nabi, M. M., Mohanty, S. K., Nabiul Afrooz, A. R. M., Cantando, E., Aich, N., et al. (2020). Detection and quantification of engineered particles in urban runoff. Chemosphere 248, 126070. doi: 10.1016/j.chemosphere.2020.126070

Westerhoff, P., Song, G., Hristovski, K., and Kiser, M. A. (2011). Occurrence and removal of titanium at full scale wastewater treatment plants: implications for $\mathrm{TiO}_{2}$ nanomaterials. J. Environ. Monit. 13, 1195-1203. doi: $10.1039 / \mathrm{clem} 10017 \mathrm{c}$

Conflict of Interest: The authors declare that the research was conducted in the absence of any commercial or financial relationships that could be construed as a potential conflict of interest.

Copyright (c) 2020 Slomberg, Auffan, Guéniche, Angeletti, Campos, Borschneck, Aguerre-Chariol and Rose. This is an open-access article distributed under the terms of the Creative Commons Attribution License (CC BY). The use, distribution or reproduction in other forums is permitted, provided the original author $(s)$ and the copyright owner(s) are credited and that the original publication in this journal is cited, in accordance with accepted academic practice. No use, distribution or reproduction is permitted which does not comply with these terms. 